Jonxis, J. H. P. \& Huisman, T. J. H. (1953). Lancet, ii, Sendroy, J. \& Cecchini, L. P. (1954). J. appl. Physiol. 428.

King, E. J. \& Armstrong, A. R. (1934). Canad. med. Ass. J. 31, 376.

Lowe, C. U., Terrey, M. \& MacLachlan, E. A. (1952). Amer. J. Dis. Child. 83, 164.

McCance, R. A., Fairweather, D. V. L., Barrett, A. M. \& Morrison, A. B. (1956). Quart. J. Med. N.S. 25, 523.

McCance, R. A., Morrison, A. B. \& Dent, C. E. (1955). Lancet, i, 131.

Milne, M. D., Stanbury, W. \& Thomson, A. E. (1952). Quart. J. Med. 21, 51 .

Moore, S. \& Stein, W. H. (1954a). J. biol. Chem. 211, 893. Moore, S. \& Stein, W. H. (1954b). J. biol. Chem. 211, 907. Neuberger, A., Rimington, C. \& Wilson, J. M. G. (1947). Biochem. J. 41, 438.

7, 1 .

Sereni, F., McNamara, H., Shibuya, M., Kretchmer, N. \& Barnett, H. L. (1955). Pediatrics, Springfield, 15, 575.

Smith, H. (1951). The Kidney. New York: Oxford University Press.

Spackman, D. H., Stein, W. H. \& Moore, S. (1958). Analyt. Chem. 30, 1190.

Stein, W. H. (1953). J. biol. Chem. 201, 45.

Stein, W. H. \& Moore, S. (1954). J. biol. Chem. 211, 915.

Westall, R. G. (1955). Biochem. J. 60, 247.

Westall, R. G. (1958). Proc. 4th int. Congr. Biochem., Vienna, p. 168.

Westall, R. G., Dancis, J. \& Miller, S. (1957). Amer. J. Dis. Child. 94, 571.

Woolf, L. I. (1951). Great Ormond Street J. 2, 77.

\title{
Studies on the Binding of ${ }^{65} \mathrm{Zn}$ by Equine Erythrocytes in vitro
}

\author{
By K. SIVARAMA SASTRY, L. VISWANATHAN, A. RAMAIAH AND P. S. SARMA \\ University Biochemical Laboratory, Madras 25, India
}

(Received 23 January 1959)

The administration of zinc to rabbits has been found to cause an increase in the zinc content of the erythrocytes unaccompanied by an increase in the content of carbonic anhydrase (Berfenstam, 1952). In humans also, the injection of ${ }^{65} \mathrm{Zn}$ was found to result in an uptake of about $10 \%$ of the injected element by the entire blood-cell mass in approximately $10 \mathrm{~min}$. The specific activity of the erythrocytes continued to rise progressively until ultimately it exceeded by two- to three-fold that of the plasma (Gibson, 1953). Sheline, Chaikoff, Jones \& Montgomery (1943) have shown that, in dogs, $10 \mathrm{hr}$. after the injection of ${ }^{65} \mathrm{Zn}$ all of the isotope is found in the erythrocyte and none in the plasma, even though initially the plasma had bound an appreciable amount of the isotope. The erythrocytes therefore have a marked capacity to take up ${ }^{65} \mathrm{Zn}$ even from a medium such as plasma, for instance, where many physiologically important metal-binding ligands are present. However, little is known about the process except that when the cells are incubated in vitro with ${ }^{65} \mathrm{Zn}$ they take up the isotope and fix it in a form that is stable to exhaustive washing with sodium chloride solution (Gibson, 1953; Tupper, Watts \& Wormall, 1951, 1952), and that carbonic anhydrase is not involved in this binding (Tupper et al. 1952). In this paper, certain features of the binding of ${ }^{65} \mathrm{Zn}$ by washed erythrocytes in vitro, and the influence of other cations, metabolic inhibitors and some amino acids on this uptake, are presented.

\section{EXPERIMENTAL}

Erythrocyte suspension. Horse blood cells, freshly obtained, were used in all experiments. The cell suspension was prepared from citrated blood by separating the erythrocytes from the plasma and repeatedly washing the cells with large amounts of iso-osmotic $\mathrm{NaCl}$ soln. $(0.9 \%)$ until free of citrate and plasma constituents. The suspension was then diluted with $0.9 \% \mathrm{NaCl}$ so that the final suspension had a total solids content of $170 \mathrm{mg} . / \mathrm{ml}$. This suspension thus had approximately the same erythrocyte content as whole blood, since the latter contains $17 \mathrm{~g}$. of haemoglobin/ $100 \mathrm{ml}$. The cells were invariably used with minimum delay after preparation of the above suspension. It was found that some differences existed between different samples of blood in zinc-binding capacity. Hence, in each set of experiments, the same sample of blood was employed.

Incubation procedure. Erythrocyte suspension (1 ml.) and $1 \mathrm{ml}$. of ${ }^{65} \mathrm{Zn}$ salt solution (preparation and activity given below) were incubated in a total volume of $4 \mathrm{ml}$. The rest of the volume was $0.9 \% \mathrm{NaCl}$ when the erythrocytes were incubated with zinc alone, or of a suitable solution in $0.9 \% \mathrm{NaCl}$ of any compound(s) whose influence on zinc uptake was to be tested. Under these conditions, the dilution of ${ }^{65} \mathrm{Zn}$ in the incubation mixture was such as to provide a final concentration of zinc of $0.25 \mathrm{~mm}$.

When the effect of metal ions was studied the procedure was somewhat different. Erythrocyte suspension (1 ml.), $1 \mathrm{ml}$. of $4 \mathrm{~mm}$ (or where desired $40 \mathrm{~mm}$ ) solution of the respective metal ion prepared in $0.9 \% \mathrm{NaCl}$ and $1 \mathrm{ml}$. of $0.9 \% \mathrm{NaCl}$ were first incubated for $2 \mathrm{hr}$. Thereafter, $1 \mathrm{ml}$. of ${ }^{65} \mathrm{Zn}$ salt solution was added and the incubation continued for another $2 \mathrm{hr}$. This procedure was adopted to eliminate, as far as possible, any differences in the final 
result brought about by probable differences in the rates of influx of the metal ions into the erythrocytes. Copper was used at much lower concentrations (10 and $100 \mu \mathrm{M}$ final concentration), since it was found to be a very powerful lysing agent at higher levels.

2:4-Dinitrophenol, glutathione, $p$-chloromercuribenzoate and cyanide were also tested at $\mathrm{mm}$ concentration in the medium, and erythrocytes were pre-incubated with the compounds in a manner similar to the above, except that the pre-incubation period was $1 \mathrm{hr}$. Several amino acids were also tested with a pre-incubation period of $30 \mathrm{~min}$. Preliminary experiments, carried out with a view to determine the optimum pre-incubation periods for each of these classes of compounds, revealed that they had different rates of migration and lead to the choice of the periods. These were optimum for the present investigation.

In all cases, all solutions were prepared in $0.9 \% \mathrm{NaCl}$, with suitable precautions to eliminate contamination from other trace elements, and adjusted to $\mathrm{pH} \mathbf{5 . 5}$ before use. Incubations were carried out in triplicate, in Pyrex test tubes of $20 \mathrm{ml}$. capacity, which were kept in a metal testtube rack in a Dubnoff metabolic incubator and shaken at room temperature $\left(30^{\circ}\right)$.

For determination of zero-time uptake of zinc by erythrocytes, $1 \mathrm{ml}$. of erythrocyte suspension was rapidly blown into $1 \mathrm{ml}$. of ${ }^{65} \mathrm{Zn}$ salt solution and $2 \mathrm{ml}$. of $0.9 \%$ $\mathrm{NaCl}$, mixed by rapid shaking for a few seconds and immediately centrifuged at $100 \mathrm{~g}$. After $2 \mathrm{~min}$., the supernatant was quantitatively separated and the cells were processed for determination of ${ }^{65} \mathrm{Zn}$.

In the experiments where the effect of $\mathrm{pH}$ on the uptake of ${ }^{65} \mathrm{Zn}$ by the cells was studied, $1 \mathrm{ml}$. of the erythrocyte suspension was taken in test tubes, centrifuged to pack the cells and the supernatant was pipetted out. ${ }^{65} \mathrm{Zn}$ in $0.9 \%$ $\mathrm{NaCl}$, adjusted to the desired $\mathrm{pH}$, was then added to bring the final volume to $4 \mathrm{ml}$. and the usual ${ }^{65} \mathrm{Zn}$ concentration. The influence of $\mathrm{pH}$ was studied at $\mathrm{pH} 4 \cdot 0,5 \cdot 5$ and $6 \cdot 0$. With whole erythrocytes, a $\mathrm{pH}$ of less than $4 \cdot 0$ could not be used since it was found to induce agglutination and lysis. Similarly, under the conditions of the present investigation, a partial precipitation of zinc was found to occur beyond pH 6.0 and hence uptake of ${ }^{65} \mathrm{Zn}$ was not studied at higher $\mathrm{pH}$.

Radioactive technique. Radioactive zinc was purchased from The Radiochemical Centre, Amersham, Bucks, and had a specific activity of $60 \mathrm{mc} / \mathrm{g}$. In one experiment (electrophoresis experiment, Fig. 2), zinc with a higher specific activity $(100 \mathrm{mc} / \mathrm{g}$.) was also employed. The zinc solution, as obtained, was ${ }^{65} \mathrm{ZnCl}_{2}$ in dilute $\mathrm{HCl}$ and was diluted with $0.9 \% \mathrm{NaCl}$ and adjusted to $\mathrm{pH} 5.5$ before use. The incubation mixture always contained about $9 \times 10^{3}$ counts/min., under the conditions of counting. The exact values in each experiment were not always identical since the experiments were performed during the course of a few months, and hence the actual number of counts has been indicated wherever necessary. However, the actual zinc concentration was constant in the incubation mixture, being $\mathbf{0 . 2 5} \mathrm{mm}$.

In all experiments, immediately after the termination of incubation with ${ }^{65} \mathrm{Zn}$, the incubation mixture was centrifuged at $2500 \mathrm{rev} . / \mathrm{min}$. for $5 \mathrm{~min}$. to stop uptake and to separate the cells from the unabsorbed ${ }^{65} \mathrm{Zn}$. The supernatant was then removed by means of a glass tube with a fine nozzle and a rubber teat, without disturbing the cells.
A portion (5 ml.) of $0.9 \% \mathrm{NaCl}$ was then added, the cells were shaken to attain uniform suspension and again centrifuged as before; the $0.9 \% \mathrm{NaCl}$ was discarded. The procedure was repeated four times in all. Preliminary tests showed that this procedure did not remove zinc taken up by the cells themselves. Control tubes were always run in the same manner and all erythrocyte samples were subjected to the centrifuging process at the same time so that the values were strictly comparable.

Radioactivity determinations of erythrocyte samples were performed by lysing the samples and making up to $10 \mathrm{ml}$. with water, in a Veall liquid counter (M6M, 20th Century Electronics Ltd.) attached to a Panax scaler of the decade type (Panax Equipment, Mitcham, Surrey). With solid samples, a weighed amount (not exceeding $10 \mathrm{mg}$.) was uniformly dispersed in a steel planchet and radioactivity measured with the aid of a bell-type Geiger counter (G.E.C. Counter, mica end-window, $2 \cdot 1 \mathrm{mg} . / \mathrm{cm}^{2}$ ) attached to the Panax scaler. All samples were counted such that the relative counting error was within $\pm 2 \%$. No self-absorption corrections have been made.

Electrophoresis of erythrocyte proteins. In one experiment it was sought to associate the major part of the radioactivity taken up by the erythrocytes with the haemoglobin by paper electrophoresis of the erythrocyte proteins. For this purpose $1 \mathrm{ml}$. of the erythrocyte suspension was mixed with $1 \mathrm{ml}$. of ${ }^{65} \mathrm{Zn}$ salt solution ( $100 \mathrm{mc} / \mathrm{g}$.) for a period of $4 \mathrm{hr}$. The cells were then washed with $0.9 \% \mathrm{NaCl}$ until completely free of unabsorbed zinc and were lysed with ether. Water $(0.5 \mathrm{ml}$.) was added, the haemolysate was centrifuged at $100 \mathrm{~g}$ to remove debris and two portions of $100 \mu \mathrm{l}$. were removed. In one of the portions the radioactivity was determined as before. A duplicate portion was then spotted on Whatman no. 1 filter paper and electrophoresis conducted for $3 \mathrm{hr}$. at $180 \mathrm{v}$ and $5.5 \mathrm{~mA}$ in an Arthur Thomas Co. Paper Electrophoresis Apparatus, in $0.05 \mathrm{M}$-veronal buffer. After electrophoresis, the strip was removed, the position of the haemoglobin band was noted and the strip cut transversely into pieces $1 \mathrm{~cm}$. wide. The ${ }^{65} \mathrm{Zn}$ from each strip was eluted by suspending it in $10 \mathrm{ml}$. of $\mathrm{N}-\mathrm{HCl}$ in a test tube for $1 \mathrm{hr}$. with intermittent shaking. A few trials conducted as checks showed that this procedure quantitatively eluted the radioactivity from the paper. After centrifuging, the solution was then counted as usual in the liquid counter.

Isolation of haemoglobin. In a second experiment, cells after having been allowed to take up ${ }^{65} \mathrm{Zn}$ were lysed by adding a little ether, followed by a few drops of water. The haemolysate was then centrifuged to separate cell debris and the clear red supernatant was set aside in the ice-chest, to crystallize the haemoglobin, after adjusting the $\mathrm{pH}$ to 6.8 (Lemberg \& Legge, 1949). After leaving the solution overnight, most of the haemoglobin was found to have crystallized in the form of big crystals and was separated by centrifuging. The supernatant was kept separate. The crystals were washed with the minimum amount of ice-cold water and the radioactivity in the haemoglobin was determined.

Dialysis and fractionation of erythrocyte proteins. The cells from the incubation mixture $(1 \mathrm{ml}$. of erythrocyte suspension, $1 \mathrm{ml}$. of ${ }^{65} \mathrm{Zn}$ salt solution in $4 \mathrm{ml}$. volume, incubated for $2 \mathrm{hr}$.) were washed free of unabsorbed ${ }^{65} \mathrm{Zn}$, lysed and the volume was made to exactly $5 \mathrm{ml}$. This haemolysate was dialysed against $40 \mathrm{ml}$. of double-distilled 
water in a $50 \mathrm{ml}$. beaker overnight at $5^{\circ}$. The water was then changed and dialysis continued. Three changes of water were made in all, over a period of $72 \mathrm{hr}$., at the end of which the lysate and the dialysis water were removed for estimation of ${ }^{65} \mathrm{Zn}$. The pooled dialysis water was evaporated to small volume, made up to $10 \mathrm{ml}$. and counted in the liquid counter. The haemolysate was also similarly treated and its radioactivity determined.

An experiment was performed in the following manner to determine broadly the distribution of radioactive zinc in erythrocyte proteins. A portion $(10 \mathrm{ml}$.) of erythrocyte suspension was incubated with ${ }^{65} \mathrm{Zn}$, under conditions similar to those described before, in $50 \mathrm{ml}$. centrifuge tubes for $2 \mathrm{hr}$. After washing with $0.9 \% \mathrm{NaCl}$ the cells were lysed and acetone was added slowly, with stirring, in an ice bath, to precipitate proteins. After the required concentration of acetone had been reached, the tubes were tightly plugged and set aside, overnight, in a refrigerator to complete precipitation. The precipitate was separated by centrifuging, washed twice with acetone of the same concentration and finally dried by washing with pure acetone. It was then dried to constant weight in vacuo and its ${ }^{65} \mathrm{Zn}$ content determined with the Geiger counter. As the primary purpose in these studies was to find out whether there were any marked variations in the specific activities of erythrocyte proteins, the fractionation was conducted in four steps and the proteins separating in the range of acetone concentration $0-25 \%, 25-50 \%$ and $50-75 \%$, and in the supernatant from the last stage, were tested. ${ }^{65} \mathrm{Zn}$ taken up by the cells was quantitatively precipitated when the acetone concentration was $75 \%$. Advantage was taken of this observation in studying the stability of bound ${ }^{65} \mathrm{Zn}$ to ethylenediaminetetra-acetate (EDTA). For this purpose, erythrocytes were incubated with ${ }^{65} \mathrm{Zn}$ for $2 \mathrm{hr}$. as usual, washed, lysed and reincubated with $4 \mathrm{ml}$. of $10 \mathrm{~mm}$ EDTA at pH 5.5. At the end of the requisite incubation period, acetone was added to $75 \%$ concentration and protein separated as above. The supernatant was evaporated, made up to $10 \mathrm{ml}$. in $75 \%$ acetone and counted. Under these conditions, the radioactivity in the $75 \%$ acetone supernatant represented the ${ }^{65} \mathrm{Zn}$ split off from the cell proteins by EDTA. The zinc in the ${ }^{65} \mathrm{Zn}$ used at the levels employed was found to be completely soluble in $\mathbf{7 5} \%$ acetone, both in the presence and in the absence of EDTA.

\section{RESULTS}

In Fig. 1 is shown the uptake of ${ }^{65} \mathrm{Zn}$ by intact equine erythrocytes as a function of the time of incubation. The uptake of ${ }^{65} \mathrm{Zn}$ is more rapid in the first $2 \mathrm{hr}$. but thereafter slows down and, eventually, at the end of $4 \mathrm{hr}$. the uptake ceases. However, even at this time, Fig. 1 reveals that the ${ }^{65} \mathrm{Zn}$ taken up constitutes only about $30 \%$ of the total present in the incubation mixture. To find out whether this represented the maximum that could be taken up by the cell proteins, the same amount of the cells (1 ml. of erythrocyte suspension) was lysed and allowed to take up ${ }^{65} \mathrm{Zn}$ under otherwise identical conditions. Uptake was stopped by adding acetone to $75 \%$ concentration. When this was done it was found that the entire amount of added ${ }^{65} \mathrm{Zn}$ $\left(9.23 \times 10^{3}\right.$ counts/min. $)$ was taken up by the erythrocyte proteins within $1 \mathrm{~min}$.

In a separate study, the effect of acetone on uptake of ${ }^{65} \mathrm{Zn}$ by the erythrocyte proteins was determined as follows, with haemolysate instead of intact cells. The haemolysate used for the purpose was made by taking a measured amount of the final erythrocyte suspension, centrifuging to pack the cells, pouring off the supernatant, lysing with water and making up once again to the original volume. Hence, in protein content, $1 \mathrm{ml}$. of haemolysate was exactly equivalent to $1 \mathrm{ml}$. of cell suspension. Haemolysate (1 ml.) was incubated with $1 \mathrm{ml}$. of ${ }^{65} \mathrm{Zn}$ salt solution $\left(9 \times 10^{3}\right.$ counts $/ \mathrm{min}$.) and $2 \mathrm{ml}$. of $0.9 \% \mathrm{NaCl}$ for $2 \mathrm{hr}$., and the protein was precipitated with acetone to $75 \%$ concentration. In this case, all the ${ }^{65} \mathrm{Zn}$ added was found to be bound to protein. Another portion of haemolysate $\left(1 \mathrm{ml}\right.$.) was incubated with ${ }^{65} \mathrm{Zn}$ as before and was then dialysed against double-distilled water for $96 \mathrm{hr}$. to remove all unbound ${ }^{65} \mathrm{Zn}$. The haemolysate was counted after dialysis and the ${ }^{65} \mathrm{Zn}$ uptake value compared with the corresponding value obtained by the normal procedure outlined before. In one typical experiment, the mean values obtained were, for whole erythrocytes, 1903 counts/min. and for the haemolysate, after dialysis, 5227 counts $/ \mathrm{min}$.

These results and those presented in Fig. 1 together indicate that the uptake of ${ }^{65} \mathrm{Zn}$ by the whole cells is much less than the total zinc-binding capacity of the intracellular proteins. The lack of uptake of ${ }^{65} \mathrm{Zn}$ by erythrocytes beyond $4 \mathrm{hr}$. is presumably due to a cessation of zinc influx into the cell interior beyond this period.

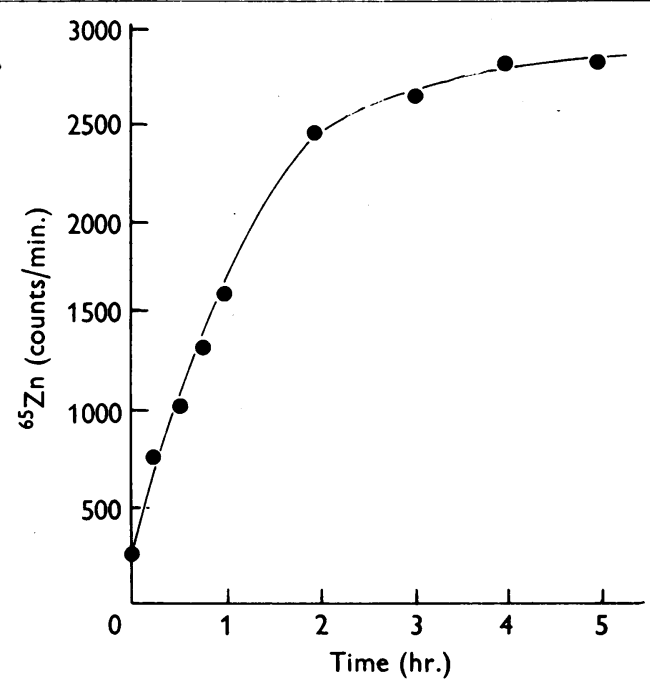

Fig. 1. Rate of uptake of ${ }^{65} \mathrm{Zn}$ by erythrocytes (total ${ }^{65} \mathrm{Zn}$ in the incubation mixture: $9 \cdot 23 \times 10^{3}$ counts/min.). For experimental details see text. 
The above results also reveal that when the erythrocyte proteins are treated with acetone in the presence of ${ }^{65} \mathrm{Zn}$ the zinc-binding capacity is apparently increased. However, acetone was found not to have any effect on zinc already bound to protein.

The stability of bound ${ }^{65} \mathrm{Zn}$ to dialysis was then examined as described earlier and the results obtained are shown in Table 1. It can be seen that the zinc taken up by the cells is entirely bound to protein and that there is little free ionic zinc inside the erythrocyte.

In Table 2 is shown the distribution of ${ }^{65} \mathrm{Zn}$ in the several protein fractions of erythrocytes. The results show that the bulk of the radioactivity is associated with haemoglobin, a conclusion supported by $(a)$ the electrophoresis pattern represented in Fig. 2 and $(b)$ the ${ }^{65} \mathrm{Zn}$ found in the haemoglobin separated by crystallization after it had taken up the isotope; $85 \cdot 3 \%$ (mean value from duplicates) was found in the haemoglobin.

The $\mathrm{pH}$ of the incubation medium was also found to influence uptake of ${ }^{65} \mathrm{Zn}$ by erythrocytes. In two sets of experiments carried out, the average uptake values at $\mathrm{pH} \mathrm{4.0,5.5}$ and 6.0 were 1108 , 1904 and 4176 counts/min. respectively.

The influence of several metabolic inhibitors and complex-forming agents on the uptake of ${ }^{65} \mathrm{Zn}$ by erythrocytes is shown in Table 3 . The absence of

Table 1. Stability of erythrocyte-bound ${ }^{65} \mathrm{Zn}$ to dialysis

For conditions of incubation and dialysis see text.

\begin{tabular}{|c|c|c|}
\hline $\begin{array}{l}\text { Expt. } \\
\text { no. }\end{array}$ & Experimental details & $\begin{array}{c}\text { Uptake } \\
\text { of }{ }^{65} \mathrm{Zn} \\
\text { (counts/min.)* }\end{array}$ \\
\hline 1 & Standard ${ }^{65} \mathrm{Zn}$ used in incubation & 9012 \\
\hline 2 & Blank (of the liquid counter used) & 14 \\
\hline 3 & $\begin{array}{l}\text { Activity in erythrocytes after } \\
\text { incubation with }{ }^{65} \mathrm{Zn}\end{array}$ & 2540 \\
\hline 4 & $\begin{array}{l}\text { Activity of lysed erythrocytes } \\
\text { after dialysis }\end{array}$ & 2510 \\
\hline 5 & Dialysis water & 17 \\
\hline
\end{tabular}

appreciable inhibition by cyanide and dinitrophenol would appear to indicate the possible absence of an energy requirement for uptake of ${ }^{65} \mathrm{Zn}$. The considerable increase in the uptake in the presence of cyanide is somewhat unexpected. The explanation for such behaviour is probably associated with the greater permeability of the zinc cyanide complex, since the limiting step in the uptake process is the influx of zinc into the intracellular space. Further, subsequent experiments showed that the effect was absent when haemolysate was used instead of whole cells, supporting such a view.

The effect of EDTA on the uptake and the stability of bound ${ }^{65} \mathrm{Zn}$ by erythrocytes was studied in two ways, and the results are shown in Table 4. It can be seen that in the presence of EDTA, no ${ }^{65} \mathrm{Zn}$ is taken up and ${ }^{65} \mathrm{Zn}$ bound to erythrocytes is removed relatively slowly by subsequent treatment with EDTA (Table 4). It seems likely that EDTA (Foreman \& Trujillo, 1954) and

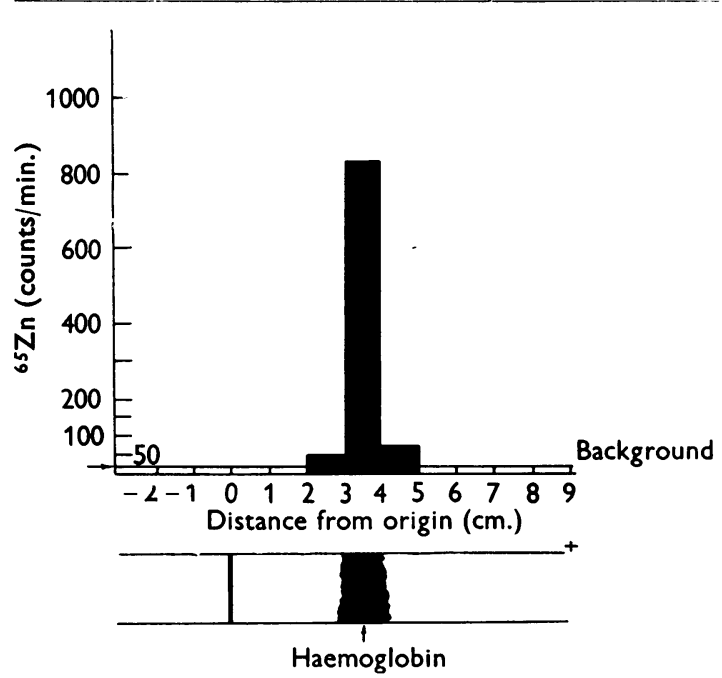

Fig. 2. Distribution of ${ }^{65} \mathrm{Zn}$ in erythrocytes $(100 \mu \mathrm{l}$. of haemolysate of erythrocytes with total count of 913 counts/min. spotted on paper). Electrophoresis was carried out as described in the text.

Table 2. Distribution of ${ }^{65} \mathrm{Zn}$ in erythrocyte proteins

For conditions of incubation and fractionation see text.

\begin{tabular}{|c|c|c|c|c|c|}
\hline \multirow[b]{2}{*}{$\begin{array}{l}\text { Fraction } \\
\text { no. }\end{array}$} & \multirow{2}{*}{$\begin{array}{l}\text { Range of acetone } \\
\text { concentration }(\%)\end{array}$} & \multirow[b]{2}{*}{$\begin{array}{l}\text { Colour of } \\
\text { protein }\end{array}$} & \multirow[b]{2}{*}{$\begin{array}{l}\text { Total wt. } \\
\text { of ppt. }\end{array}$} & \multicolumn{2}{|c|}{${ }^{65} \mathrm{Zn}$ content (counts/min.)* } \\
\hline & & & & Total & Content/mg. \\
\hline $\begin{array}{l}\text { I } \\
\text { II } \\
\text { III } \\
\text { IV }\end{array}$ & $\begin{array}{l}0-25 \\
25-50 \\
50-75 \\
\text { Supernatant from III }\end{array}$ & $\begin{array}{l}\text { Pale rose } \dagger \\
\text { Rose red } \\
\text { White }\end{array}$ & $\begin{array}{l}1.8 \mathrm{mg} . \\
1.7 \mathrm{~g} . \\
3.3 \mathrm{mg} .\end{array}$ & $\begin{array}{r}118 \\
24610 \\
46\end{array}$ & $\begin{array}{l}65 \cdot 5 \\
14 \cdot 5 \\
13 \cdot 9 \\
\text { Nil }\end{array}$ \\
\hline
\end{tabular}

* Total ${ }^{65} \mathrm{Zn}$ added at the incubation stage was $11.5 \times 10^{1}$ counts $/ \mathrm{min}$.

$\dagger$ This fraction included stromata and cell debris. 
zinc-EDTA complex do not penetrate the erythrocyte. Another important feature is that EDTA splits off bound ${ }^{65} \mathrm{Zn}$ only very slowly, the process going to completion only after somewhat more than $2 \mathrm{hr}$.

Table 5 summarizes the effect of other cations on the uptake of ${ }^{65} \mathrm{Zn}$ by erythrocytes: among the cations tested, only $\mathrm{Fe}^{3+}$ and, to a much smaller extent, $\mathrm{Cu}^{2+}$ ions are definitely inhibitory to the process of uptake. The concentration of $\mathrm{Cu}^{2+}$ ions in these experiments was one-hundredth of that of $\mathrm{Fe}^{3+}$ ions. The influence of these cations was also studied with the haemolysate instead of whole erythrocytes by the technique described above. Only $\mathrm{Fe}^{3+}$ was inhibitory, to the extent of $25.2 \%$ (control, 2560 counts/min.; with $3 \mathrm{mM}-\mathrm{Fe}^{3+}$, 1928 counts $/ \mathrm{min}$.; ${ }^{65} \mathrm{Zn}$ added was $9.7 \times 10^{3}$ counts/ min.).

Christensen \& Riggs (1956) have offered evidence for the beneficial influence of chelate formation on the transfer of amino acids (and consequently of the

Table 3. Influence of some metabolic inhibitors and related compounds on uptake of ${ }^{65} \mathrm{Zn}$ by erythro. cytes

For conditions of incubation see text. Concentration of the tested compounds in the incubation mixture was $1 \mathrm{~mm}$.

$\begin{array}{llc}\text { Compound tested } & \begin{array}{c}\text { Uptake } \\ \text { of }{ }^{65} \mathrm{Zn}\end{array} \\ \text { (counts } / \mathrm{min} . \text { ) }^{*} & \text { Control (none) } & 2443 \\ 2 \text { Sodium cyanide } & 7287 \\ 3 & 2: 4 \text {-Dinitrophenol } & 1801 \\ 4 & p \text {-Chloromercuribenzoate } & 2566 \\ 5 & \text { Glutathione } & 224 \\ & *{ }^{65} \mathrm{Zn} \text { added: } 8.52 \times 10^{3} \text { counts } / \mathrm{min} .\end{array}$

Table 4. Influence of ethylenediaminetetra-acetate on ${ }^{65} \mathrm{Zn}$ binding by erythrocytes

A : $1 \mathrm{ml}$. of erythrocyte suspension was incubated with EDTA and ${ }^{65} \mathrm{Zn}\left(9 \times 10^{3}\right.$ counts/min. $)$ for $2 \mathrm{hr}$., the cells being thereafter processed for determination of uptake as usual. B: erythrocytes, after having been allowed to take up ${ }^{65} \mathrm{Zn}$ as in A, but without EDTA, were lysed and reincubated with EDTA at pH 5.5; after incubation, the protein was precipitated by adding acetone to $75 \%$ concentration, and the acetone supernatant counted to determine the amount of zinc split off by EDTA.

A. Influence of EDTA on ${ }^{65} \mathrm{Zn}$ binding

(1) Control (no EDTA)

(2) With 1 mm-EDTA and ${ }^{65} \mathrm{Zn}$

(3) With $10 \mathrm{~mm}$-EDTA and ${ }^{65} \mathrm{Zn}$

B. Effect of EDTA on ${ }^{65} \mathrm{Zn}$ bound by erythrocytes

(1) Control

(2) Incubated with 10 mM-EDTA

(i) For $2 \mathrm{hr}$.

(ii) For $3 \mathrm{hr}$.

(iii) For $4 \mathrm{hr}$. metal ions associated with such complexes) into living cells. It was thought of interest therefore to find out whether amino acids have any influence on the uptake of ${ }^{65} \mathrm{Zn}$ by erythrocytes. The results of such a study are shown in Table 6. It will be evident that several of the amino acids are inhibitory. However, none of the amino acids was inhibitory to the uptake of ${ }^{65} \mathrm{Zn}$ by haemolysate.

\section{DISCUSSION}

The results obtained in this investigation have revealed several features of zinc uptake by whole erythrocytes in vitro. They are in agreement with the findings of Tupper et al. (1952) that the ${ }^{65} \mathrm{Zn}$ taken up is fairly stable and is entirely bound to erythrocyte protein. It can be seen that this uptake is also markedly influenced by the $\mathrm{pH}$ of the incubation medium, showing that the presence of $\mathrm{H}^{+}$ions in excess is detrimental to the process. From the data of Table 2 it would appear that there is little free $\mathbf{Z n}^{2+}$ in the intracellular space, since the $75 \%$ acetone supernatant, which is free of protein, is also free of radioactivity. Even though the uptake of ${ }^{65} \mathrm{Zn}$ is increased when the haemolysate is incubated with ${ }^{65} \mathrm{Zn}$ in the presence of acetone, acetone by itself was found to have no effect on ${ }^{65} \mathrm{Zn}$ taken up by erythrocyte proteins. Thus the distribution of ${ }^{65} \mathrm{Zn}$ among the erythrocyte proteins as shown in Table 2 is essentially representative of the capacity of the several proteins in this respect. Doubts have earlier been expressed (cf. Gibson, 1953) whether the ${ }^{65} \mathrm{Zn}$ taken up by the erythrocytes represented that bound to the cell membrane itself or whether it entered the cell and was bound inside. From 
Table 5. Influence of metal ions on ${ }^{65} \mathrm{Zn}$ uptake by erythrocytes in vitro

For conditions of incubation see text.

\begin{tabular}{|c|c|c|c|}
\hline \multirow[b]{2}{*}{$\begin{array}{l}\text { Expt. } \\
\text { no. }\end{array}$} & \multirow[b]{2}{*}{$\begin{array}{l}\text { Metal ion tested } \\
\text { and salt employed }\end{array}$} & \multicolumn{2}{|c|}{$\begin{array}{l}\text { Uptake of }{ }^{65} \mathrm{Zn} \\
\text { (counts/min.)* }\end{array}$} \\
\hline & & $\begin{array}{l}\text { Concn. } \\
1 \mathrm{~mm}\end{array}$ & $\begin{array}{l}\text { Conen. } \\
10 \mathrm{~mm}\end{array}$ \\
\hline $\begin{array}{l}1 \\
2 \\
3 \\
4 \\
5 \\
6 \\
7\end{array}$ & $\begin{array}{l}\text { None (control) } \\
\mathrm{Fe}^{3+}\left(\mathrm{FeCl}_{3}\right) \\
\mathrm{Co}^{2+}\left(\mathrm{CoCl}_{2}\right) \\
\mathrm{Mn}^{2+}\left(\mathrm{MnSO}_{4}\right) \\
\mathrm{Ca}^{2+}\left(\mathrm{CaCl}_{2}\right) \\
\mathrm{Cd}^{2+}\left(\mathrm{CdSO}_{4}\right) \\
\mathrm{Cu}^{2+}\left(\mathrm{CuSO}_{4}\right)\end{array}$ & $\begin{array}{c}108 \\
2788 \\
3030 \\
2942 \\
3041 \\
(2594) \S\end{array}$ & $\begin{array}{c}{ }^{\dagger} \dagger \\
332 \ddagger \\
3114 \\
2870 \\
-\dagger \\
(1891) \|\end{array}$ \\
\hline \multicolumn{4}{|c|}{${ }^{65} \mathrm{Zn}$ added in the incubation mixtures: $9 \times 10^{3}$ count } \\
\hline
\end{tabular}

Table 6. Influence of amino acids on uptake of ${ }^{65} \mathrm{Zn}$ by erythrocytes

The ${ }^{65} \mathrm{Zn}$ added was as in earlier experiments, but due to decay provided only $6 \times 10^{3}$ counts $/ \mathrm{min}$.

\begin{tabular}{|c|c|c|}
\hline $\begin{array}{c}\text { Expt. } \\
\text { no. }\end{array}$ & Amino acid tested & $\begin{array}{c}\text { Uptake } \\
\text { of }{ }^{65} \mathrm{Zn} \\
\text { (counts/min.) }\end{array}$ \\
\hline 1 & None (control) & 1220 \\
\hline 2 & Histidine & 124 \\
\hline 3 & Lysine & 680 \\
\hline 4 & Glutamic acid & 732 \\
\hline 5 & Leucine & 802 \\
\hline 6 & Glycine & 943 \\
\hline 7 & Arginine & 972 \\
\hline 8 & Methionine & 1000 \\
\hline 9 & Tyrosine & 1185 \\
\hline
\end{tabular}

Table 2 it may be inferred that little zinc is bound by the cell membrane itself, since fraction I (Table 2), which contains stromata and cell debris and comparatively little other protein matter, contains a negligible amount of the total radioactivity taken up by the cells, though the specific activity is higher than that of haemoglobin.

The uptake of ${ }^{65} \mathrm{Zn}$ reaches a maximum in $4 \mathrm{hr}$., and hence is comparatively faster than the uptake of iron in duck erythrocytes, which is known to require $6 \mathrm{hr}$. (Sharpe, Krishnan \& Klein, 1952). However, the reason why the uptake of ${ }^{65} \mathrm{Zn}$ should normally fall short of the total binding capacity is not clear. As indicated by the unique effect of cyanide (Table 3 ) and the observed binding capacity of the haemolysate, the phenomenon is probably unrelated to a limited binding capacity or to a normal barrier to the influx of the metal ion. It is possible that continued exposure of erythrocytes to $\mathrm{Zn}^{2+}$ ions, under the conditions of the experiments, has an adverse effect on the cell membrane resulting in decreased permeability. The wellknown protein-precipitating ability of $\mathrm{Zn}^{2+}$ ions, and the fact that exposure of erythrocytes to mMconcentration and above of $\mathrm{Zn}^{2+}$ ions was found to result in an immediate clumping of the cells, followed by lysis, support such a hypothesis.

During recent years, various investigations have been reported (Sharpe et al. 1952; Boiron, Paoletti \& Tubiana, 1955; Fleckenstein, Gerlach \& Janks, 1956; Saltman, Fiskin \& Bellinger, $1956 a$; Saltman \& Boroughs, 1958; Pal, 1958; Clarkson \& Kench, 1958) on the capacity of erythrocytes, as well as cells from other tissues such as liver, to bind ions such as $\mathrm{Fe}^{3+}, \mathrm{Pb}^{2+}$ and $\mathrm{Mn}^{2+}$. A comparison of the results of the present investigation with some of the data for the other cations reveals several interesting points. As with liver tissue with ${ }^{65} \mathrm{Zn}$ (Saltman \& Boroughs, 1958) and ${ }^{59} \mathrm{Fe}$ (Saltman et al. $1956 a$; Saltman, Fiskin, Bellinger \& Alex, 1956b) the uptake of $\mathbf{Z n}^{2+}$ ions by erythrocytes appears to be largely a passive process. Further, erythrocytes seem to possess different binding properties for different cations in view of the differences exhibited in $\mathrm{Pb}^{2+}$ binding (Clarkson \& Kench, 1958) and ${ }^{65} \mathrm{Zn}$ binding; with the former ion the binding appears to be reversible and up to $25 \%$ of the total is present at the cell membrane, whereas little zinc appears to be bound at the cell surface.

The effects of other cations on zinc uptake show the great degree of specificity involved in the binding of ${ }^{65} \mathrm{Zn}$ by the erythrocytes. It is difficult on the basis of available literature to say whether the various ions exhibit comparable rates of diffusion across the erythrocyte membrane. However, in view of the fact that the erythrocytes had been pre-incubated with the cations tested for an overall period of $4 \mathrm{hr}$., at a concentration of at least four times that of the zinc in the medium, it is quite probable that under the present experimental conditions an adequate concentration of the respective metal ions would have been present to compete effectively with ${ }^{65} \mathrm{Zn}$. The uptake values in the presence of the cations, as shown by Table 5 , reflect the capacity therefore of the several cations to compete with ${ }^{65} \mathrm{Zn}$ for binding by the erythrocytes. Neither cobalt, which also forms strong complexes with histidine (Hearon, Schade, Levy \& Burk, 1947), nor cadmium, which is known to behave very much like zinc in binding to proteins (cf. Tanford, 1952), has any effect on zinc uptake at $\mathrm{mm}$ concentration. $\mathrm{Fe}^{3+}$ is the most powerful inhibitor of zinc uptake, a very significant finding in view of the fact that several investigators have found that one of the biochemical lesions of zinc toxicity is an interference with iron utilization as reflected in abnormally low levels of cytochrome oxidase and catalase (van Reen, 1953; van Reen \& Pearson, 1953; Sivarama Sastry \& Sarma, 1958). 
Probably, in many cells, as in erythrocytes, iron and zinc may bind at similar sites. Holmberg \& Laurell (1947) have found that iron can even displace zinc bound by serum albumin. However, the fact that none of the ions is inhibitory with haemolysate (even iron is much less inhibitory than with whole erythrocytes) reveals that the influence of other ions is mostly exerted at the cell surface.

However, unlike the penetration of ${ }^{50} \mathrm{Fe}$ into erythrocytes (Boiron et al. 1955) and the influx of $\mathrm{Mn}^{2+}$ into ascites tumour cells (Pal, 1958) the influx of ${ }^{65} \mathrm{Zn}$ is inhibited by the amino acids. It is not surprising that histidine, an amino acid whose capacity for binding zinc is capable of quantitatively accounting for zinc binding by proteins (Tanford, 1952; Gurd \& Goodman, 1952), is also the strongest inhibitor of ${ }^{65} \mathrm{Zn}$ uptake by the erythrocytes. The influence of the amino acids, as shown by Table 6 , reflects only their effect on the transport of ${ }^{65} \mathrm{Zn}$ across the erythrocyte membrane since they have no effect on ${ }^{65} \mathrm{Zn}$ uptake by the haemolysate.

\section{SUMMARY}

1. It has been shown that equine erythrocytes take up ${ }^{65} \mathrm{Zn}$ from iso-osmotic sodium chloride solution and bind it strongly. The bound zinc was stable to dialysis and was associated to a major extent with haemoglobin. The uptake of ${ }^{65} \mathrm{Zn}$ by whole erythrocytes as well as by a haemolysate prepared from them was studied under different conditions and it was shown that the total zinc bound by the whole cells was somewhat less than the total binding capacity of the erythrocyte proteins for zinc.

2. Very little of ${ }^{65} \mathrm{Zn}$ was bound at the cell membrane, most of it diffusing across the cell wall and becoming bound to intracellular erythrocyte proteins. This uptake process was rapid in the first $2 \mathrm{hr}$. and was thereafter slow, reaching a maximum in $4 \mathrm{hr}$.

3. Ethylenediaminetetra - acetate completely inhibited uptake of ${ }^{65} \mathrm{Zn}$ by whole erythrocytes but detached bound ${ }^{65} \mathrm{Zn}$ only very slowly. Among several metabolic inhibitors tested, cyanide markedly increased the uptake of zinc by erythrocytes.

4. $\mathrm{Fe}^{3+}, \mathrm{Co}^{2+}, \mathrm{Mn}^{2+}, \mathrm{Ca}^{2+}, \mathrm{Cd}^{2+}$ and $\mathrm{Cu}^{2+}$ ions were tested for their capacity to influence uptake of ${ }^{65} \mathrm{Zn}$ by erythrocytes. Only $\mathrm{Fe}^{3+}$ was powerfully inhibitory at mM concentration; it was much less inhibitory towards uptake by haemolysed erythrocytes.

5. Histidine, lysine, glutamic acid, leucine, glycine, arginine and methionine inhibited uptake of ${ }^{65} \mathrm{Zn}$ by erythrocytes to varying degrees. At $1 \mathrm{~mm}$, histidine was the most inhibitory, depressing uptake by $90 \%$. However, none of the amino acids had any effect of the uptake by erythrocyte haemolysate.

\section{REFERENCES}

Berfenstam, R. (1952). Acta paediat. 41, 389, Suppl. 87, p. 105.

Boiron, M., Paoletti, C. \& Tubiana, M. (1955). C.R. Acad. Sci., Paris, 241, 1165.

Christensen, H. N. \& Riggs, T. R. (1956). J.biol. Chem.220, 265.

Clarkson, T. W. \& Kench, J. E. (1958). Biochem. J. 69, 432 .

Fleckenstein, A., Gerlach, E. \& Janks, T. (1956). Schweiz. med. Wschr. 86, 1041.

Foreman, H. \& Trujillo, T. T. (1954). J. Lab. clin. Med. 43, 566.

Gibson, J. G. (1953). In Blood Cells and Plasma Proteins, p. 202. Ed. by Tullis, J. L. New York: Academic Press Inc.

Gurd, F. R. N. \& Goodman, D. S. (1952). J. Amer. chem. Soc. 74, 670.

Hearon, J., Schade, A. L., Levy, H. \& Burk, D. (1947). Cancer Res. 7, 713.

Holmberg, C. G. \& Laurell, C. B. (1947). Acta chem. scand. $1,944$.

Lemberg, R. \& Legge, J. M. (1949). In Hematin Compounds and Bile Pigments, p. 212. New York: Interscience Publishers Inc.

Pal, P. R. (1958). Fed. Proc. 17, 286.

Saltman, P. \& Boroughs, H. (1958). Fed. Proc. 17, 262.

Saltman, P., Fiskin, R. D. \& Bellinger, S. B. (1956a). J. biol. Chem. $220,741$.

Saltman, P., Fiskin, R. D., Bellinger, S. B. \& Alex, T. $(1956$ b). J. biol. Chem. 220, 751.

Sharpe, L. M., Krishnan, P. S. \& Klein, J. R. (1952). Arch. Biochem. Biophys. 35, 409.

Sheline, G. E., Chaikoff, I. L., Jones, H. B. \& Montgomery, M. L. (1943). J. biol. Chem. 147, 409.

Sivarama Sastry, K. \& Sarma, P. S. (1958). Nature, Lond., $182,533$.

Tanford, C. (1952). J. Amer. chem. Soc. 74, 211.

Tupper, R., Watts, R. W. E. \& Wormall, A. (1951). Biochem. J. 48, xxxvii.

Tupper, R., Watts, R. W. E. \& Wormall, A. (1952). Biochem. J. 50, 429.

van Reen, R. (1953). Arch. Biochem. Biophys. 46, 337.

van Reen, R. \& Pearson, P. B. (1953). Fed. Proc. 12, 283. 